\title{
Connecting the Threads: Archaeology of Reform / Archaeology as Reform
}

\author{
Megan E. Springate ${ }^{1}$
}

Published online: 20 April 2017

(C) Springer Science+Business Media New York 2017

\begin{abstract}
The papers in this issue come out of the Archaeology of Reform/Archaeology as Reform session at the 2013 meeting of the Society for Historical Archaeology in Leicester, England. Focusing on many different institutions and programs, this volume was brought together to explore the idea of social reform as it manifests in different ways in different places. At its very basic level, reform is about change - change that carries with it the implication of an improvement ranging from the personal to the social and institutional. As a noun, reform is the "amendment of what is defective, vicious, corrupt, or depraved;" as a verb, reform is to "put into a new and improved form or condition; to restore to a former good state, or bring from bad to good; to change from worse to better; to amend; to correct" (Webster and Porter 1913). Unlike revolution, which has connotations of rapid, wholesale change, reform is generally understood to be a gradual process that improves, rather than overthrows, the status quo. While the papers in this volume touch on all of these, the emphasis is on social and institutional reform affecting categories of people, rather than specific individuals. Although each paper examines a different geographic location, they share several common threads: the goals and ideologies of reform; the reformers and the reformed; material implementations of reform; and the unobtainable ideal. In addition to discussing historical reform using archaeological methods, authors were also asked to think about how archaeology itself can be reformative (archaeology as reform).
\end{abstract}

Keywords Reform $\cdot$ Negotiation and Resistance $\cdot$ Purification

\section{Introduction}

The papers in this issue derive from of the Archaeology of Reform/Archaeology as Reform session at the 2013 meeting of the Society for Historical Archaeology in

Megan E. Springate

meganspringate@gmail.com

1808 Kennebec Ave., Apt 2, Takoma Park, MD 20912, USA 
Leicester, England. These papers, focusing on many different institutions and programs, were brought together to explore the idea of social reform as it manifests in different ways in different places. At its very basic level, reform is about change - change that carries with it the implication of an improvement ranging from the personal to the social and institutional. As a noun, reform is the "amendment of what is defective, vicious, corrupt, or depraved;" as a verb, reform is to "put into a new and improved form or condition; to restore to a former good state, or bring from bad to good; to change from worse to better; to amend; to correct" (Webster and Porter 1913). Unlike revolution, which has connotations of rapid, wholesale change, reform is generally understood to be a gradual process that improves, rather than overthrows, the status quo. While the papers in this volume touch on all of these, the emphasis is on social and institutional reform affecting categories of people, rather than specific individuals. Subjects of reform can be classes of people, including aboriginal people (Flexner, this volume), the insane (Longhurst, this volume), the "worthy" poor (Spencer-Wood and Blackburn; Thomas; Carstairs, this volume; Springate 2017), or children (McKerr et al.; Beisaw and Baxter; Spencer-Wood and Blackburn, this volume). They can be institutions, like schools (McKerr et al.; Beisaw and Baxter, this volume) or mental institutions (Longhurst, this volume). They can be entire nations (Sables, this volume). Although each paper examines a different geographic location, they share several common threads: the goals and ideologies of reform; the reformers and the reformed; material implementations of reform; and the unobtainable ideal. In addition to discussing historical reform using archaeological methods, authors were also asked to think about how archaeology itself can be reformative (archaeology as reform).

Archaeology is uniquely positioned to contribute to studies of historical reform. Missing from many historians' studies of reform movements is a consideration of the material aspects of reform: how objects, landscapes, and built structures have been used to embody and enforce reform ideals. Archaeology is especially suited to looking at these material aspects of reform, as well as material evidence of resistance and negotiation between and among both the reformed and the reformers. While various institutions of reform such as schools, asylums, and poorhouses have been investigated archaeologically, they have generally been discussed in the context of others of their type (e.g., Beisaw and Gibb 2009; De Cunzo 1995, 2001, 2006; Piddock 2001; Spencer-Wood and Baugher 2001), or most recently, within the context of colonialism (McAtackney and Palmer 2016). This volume examines reform more broadly; by presenting these various institutions and examples of reform projects side-by-side, key similarities become evident. Not all of these papers incorporate subsurface archaeological investigations into their analyses; however, they all apply archaeological methods to examine how built environments, landscapes, and other materialities have been used (and continue to be used) to enact and/or resist reform ideologies. By examining the goals and ideologies of reform, reform as physical and spiritual purification, negotiation and resistance, material implementations of reform, and reform as an unobtainable ideal, this introductory essay provides a broader context for the rest of the papers and connects them to broader research efforts. This introduction concludes with a discussion of archaeology as reform. 


\section{Goals and Ideologies of Reform}

The modern idea of reform is deeply rooted in the social changes that accompanied capitalism, the industrial revolution, the development of the middle class, and, with its origins in England, colonialism. The idea of political reform and reformers had existed for many centuries in England before 1780, but it was during Christopher Wyvill's Association movement that the modern idea of reform first gained traction. The Association movement, which lasted until 1782, had "parliamentary reform" as its main goal; it developed among the growing middle class in large part "to mobilize the political classes against the government and its disastrous American War" (Innes 2003: 71). While the concept waxed and waned over the next decades, the idea of reform as positive social change persisted (Innes 2003). Reform movements in the United Kingdom from the late eighteenth through the early twentieth centuries gradually increased political democracy and generally (though not universally) improved the economic and social conditions of all citizens. These included electoral reform (including giving all men and women the right to vote), reform of the Poor Laws, educational reform, and prison reform (Burns and Innes 2003; Evans 1999; Murray 1999) driven largely by members of the middle classes.

Reform movements in the United States were also rooted in social changes brought on by industrialization, the development of the middle class, and colonialism. They ranged from early struggles for women's suffrage and religious reforms of the midnineteenth century to the many and varied social reform movements of the latenineteenth and early twentieth century Progressive Era (Berkin 2011). This era is defined by its response to the Gilded Age, when robber barons and captains of industry wrung the working and middle classes dry and lived like American royalty. Reforms of the Progressive Era in the United States included labor laws, women's suffrage, education reforms, health reforms, and the development of social programs. Scholars of the Progressive Era examining the motivations of the era's largely middle class reformers have focused on the middle-class as protective of their social status in the face of increasing working-class power and immigration (McGerr 2003); others see reformers as working with benevolent intent, like connecting isolated individuals and communities with the modern world (Weibe 1967) and improving people's lives by supporting democracy and social welfare (Muncy 1991). In reality, however, many reform projects and reformers had multiple motivations. Those running soup kitchens, for example, "were usually motivated by a combination of piety, humanitarianism, utilitarianism, and probably self-interest (preventing unrest, ensuring a good supply of cheap labor, reinforcing the social hierarchy, or enhancing one's social standing)... [And yet,] these explanations underestimate the complexity of people's motives" (Carstairs, this volume). Motivations for the reform projects in this volume vary, but all have some aspect geared towards the control or mitigation of what are perceived to be disruptive or dangerous elements of society.

\section{Reform as Physical and Spiritual Purification}

All reform projects are undertaken with a purpose, and none occur without political and social context. Some of the authors in this volume specifically address the roots of the 
reform drive. Flexner (this volume) finds the roots of reform that separates the dangerous other from the virtuous reformer in the Enlightenment and the development of modernity. For example, the "great confinement" of the sixteenth century isolated and separated those who threatened the social order from society. These included those deemed insane or criminal and later included the physically ill as well as non-Christians deemed spiritually impure. Many reform projects have a colonial or paternalistic quality to them, including those that involve the imposition of morality, acceptability, and middle class values onto subordinate or less powerful populations like immigrants or working class people. In his essay, Sables (this volume) traces decades of shifts in how the government of the United Kingdom has reformed the meanings of being British by foregrounding and prioritizing certain histories over others, and how these curated national memories have impacted the protection and perception of place.

These disruptive or dangerous elements are most often groups of people. In the South Pacific, for example, non-Christian aboriginal peoples were considered dangerous and impure, and missionaries in the region worked to Christianize and "civilize" the local populations through religious reform. This religious purification also made the South Pacific islands "safe" for the missionaries (Flexner, this volume). Beginning in the mid-nineteenth century, Hawaiians sick with Hansen's disease (formerly known as leprosy) were considered physically impure and dangerous, and were quarantined on the island of Moloka'i. This quarantine was framed as a means of cleansing the Hawaiian population by removing the ill, thereby ensuring their survival. This "purification" of Hawaiians continued through 1969, well beyond the discovery of successful treatments for leprosy as early as the 1940s and despite the fact that it is not particularly contagious (National Institute of Allergy and Infectious Diseases 2011; Flexner, this volume).

Purification as reform has not just been limited to colonial contexts. The Magdalen Society operated a refuge (also called an asylum) from 1808 to 1915 in Philadelphia as a place where "fallen women" (women working as prostitutes and others who had become pregnant out of wedlock), in the face of social opprobrium, could go. The goal of the Magdalen Society was to reform (purify) these women by teaching them housekeeping skills so that they could get jobs as domestic servants. A $13 \mathrm{f}$. (3.9 m) high wall surrounded the compound, keeping the women from interacting (polluting) the surrounding neighborhood. In 1877, the Magdalen's changed their focus, and began taking in younger women to teach them domestic skills to prevent them from "falling" (and therefore keeping Philadelphia society pure) rather than reforming them afterwards. Archaeological excavations at the Magdalen Society grounds have provided material evidence of the changing reform programs of the organization (De Cunzo 1995, 2001). St. John's Reformatory in Australia likewise protected society from the ills of wanton women, enculturating them into acceptable citizens (de Leiuen 2015). Other groups of people have also been isolated from their communities as a means of protecting society from their perceived dangerous and unpredictable natures and of reforming them. Archaeological investigations of this phenomenon have included the mentally ill (Longhurst, this volume; Spencer-Wood and Baugher 2001); the poor (Thomas, this volume; Baugher 2001; Huey 2001; Piddock 2001; Spencer-Wood 2001); criminals (Bush 2000; Casella 1999, 2000); and other institutions of confinement (Baugher 2010; Beisaw and Gibb 2009; Casella 2007; De Cunzo 2006; Myers and Moshenska 2011; Mytum and Carr 2013). 
Children hold a special place in the ideology of reformers. They are often seen as more malleable and able to be reformed, and then to carry those reforms into the world. This philosophy was explicitly put into practice in the US in the form of Indian boarding schools (Lindauer 2009; Surface-Evans 2016). In other studies, the ability of children to be reformed and their power in carrying those changes into the world are examined in the context of socialization (see, for example, Baxter 2005, 2008). In the nineteenth century, Northern Ireland created a national, ostensibly non-sectarian, school system that brought Protestant and Catholic children into the same schools. This reform of the school system (itself an institution of reform) had the main goal of reforming society by introducing and fostering values of peace and tolerance between Protestant and Catholic citizens. By growing up together, it was hoped that the political and religious strife between the groups could be mitigated and peace become a possibility (McKerr et al., this volume). Also aimed at children, playgrounds in America were created to provide children a safe place to play, away from "bad influences" including bullies, street gangs, dance halls, and other areas perceived by the middle-class organizers as unsafe. They were targeted to working class and immigrant neighborhoods as part of a moral reform program aimed at raising working class and immigrant children who respected the law, worked hard (stemming from the belief that poverty equated to laziness), and avoided corruption and juvenile delinquency (Spencer-Wood and Blackburn, this volume).

In nineteenth century United States, the differences between rural and urban education were perceived as a threatening and dangerous, a situation that was reformed through standardization. With "too many" women teaching in rural schools and a lack of control over curriculum and implementation, there was a push to implement statewide educational standards that encompassed not just what was taught, but the design and layout of the school buildings themselves (Beisaw and Baxter, this volume). The use of standardization (in individual behavior, in procedures, and in the built environment) as a tool of reform is a common thread throughout the papers in this volume. Even in Sables' paper (this volume), which discusses the political uses of heritage, he describes how certain histories and associated structures have been emphasized by the UK government over time to promote particular cultural narratives. In other contexts, archaeologists have explored the effects of standardization and personal discipline in changing people's relationships with each other and society (i.e., Hodge 2014; Shackel 1993) and the deeply entwined relationships among politics, memory, storytelling, and the past that are used, consciously and otherwise, to support particular narratives (i.e. Leone et al. 1987; Meskell 2002; Shackel 2001).

Whether implemented to purify and tame non-Christians or the working classes, to tell a sanitized and politically expedient history, or to reduce the threat of too many women teachers, the goals and means of reform were mitigated by the gender, class, race, and age of those targeted. In US schools, for example, not only were Black and white children educated separately, and boys and girls treated differently, but the "overabundance" of teachers who were women were seen by some as part of the "rural school problem" (Beisaw and Baxter, this volume). In US schools, Ulster workhouses, and American playgrounds, boys and girls received different training to make them useful members of the community: boys learned manual labor and industry while girls were trained in domestic skills (Thomas, Beisaw and Baxter, Spencer-Wood and Blackburn, all this volume). Reform projects were almost always organized around 
multiple axes of identity. For example, playgrounds were targeted to young, white, working class children, with differences depending on the gender and age of the intended recipients (Spencer-Wood and Blackburn, this volume). While many archaeological interpretations focus on single aspects of identity (like class, gender, and race) to the practical exclusion of others, intersectional analysis is increasingly being done with some success (Battle-Baptiste 2011; Blackmore 2011; Hollimon 2000, 2009; Voss 2008), including in looking at reform projects (Springate 2017).

\section{Negotiation and Resistance}

While many reform projects describe actions of reform being imposed upon the subjects, scholarship makes it clear that those who were the targets of reform efforts were never passive recipients. Negotiation, open resistance, and cultural differences were some of the ways that reform subjects (and even reformers themselves) mediated and altered the types and impacts of reform "on the ground." In Northern Ireland and in the US, the implementation of standardized schooling, including the construction of schoolhouses and grounds, varied according to how individual communities negotiated tensions between local needs and the pressures of standardization which, depending on the distance from centralized offices, may not be actively enforced (McKerr et al., and Beisaw and Baxter, this volume). Likewise, missionaries often complained that people who had seemed enthusiastic converts would revert to their "old ways" once they were no longer under the direct supervision of the missionaries (Flexner, this volume). Other archaeological studies of power relationships also look at resistance (Marshall 2009; Spencer-Wood and Baugher 2010). Eleanor Casella (2000) and Sherene Baugher (2010) both examine resistance to authority in institutional reform contexts; James Delle (1998) looks at power relationships and resistance in the context of Jamaican coffee plantations; and Hadley Kruczek-Aaron (2008) examines resistance exerted within a single household. In institutional reform contexts, resistance to authority includes breaking the rules - for example, hoarding contraband items (Casella 2000) or drinking where it is not permitted (Baugher 2010). This type of resistance is often clandestine, to avoid the consequences of being caught, and evidence is often hidden.

In these examples, both the reformers (administrators and managers) and the reformed (inmates and children) modified the ideal. Needing more space for inmates, administrators of both asylums and workhouses diverged from the prescribed ideal housing that separated inmates by gender and had those requiring the most support and treatment housed closest to the interior and furthest from the outside world (Thomas and Longhurst, this volume). Asylum inmates resisted these categorizations and organizations by insisting on gathering for religious services, despite prohibitions on both mingling and religion. As a means of maintaining order, asylum managers permitted these particular infractions (Longhurst, this volume). In American playgrounds, children both openly negotiated with the playground providers by insisting on certain services, and indirectly by abandoning those playgrounds where reformers were unavailable or unwilling to protect them from bullies, organize games, or provide discipline (Spencer-Wood and Blackburn, this volume; see Wilkie 2000 for a broader discussion of children having agency and the ability to negotiate). In his discussion of reform in a missionary/colonial context, Flexner (this volume) describes the creation of 
"hybrid" cultures where some types of resistance to reform are tolerated or allowed. This approach promises to be a rich area of investigation for those interested in the dynamic between reform and resistance.

\section{Material Implementations of Reform}

All of the papers in this volume engage with power dynamics. Although reform can be directed at oneself, these papers focus on social reform, imposed upon groups by other groups. In all cases, objects, landscapes, and structures served to make the reform ideologies manifest by materializing "conceptual definitions and boundaries in the physical world" (Flexner, this volume). Many of the papers in this issue engage with the materiality of reform in the context of powered cultural landscapes: landscapes that are created or altered to express or reinforce power relationships among and between groups of people (Spencer-Wood and Baugher 2010). Landscapes can be designed to reinforce and express differences between many different identities simultaneously. At the nineteenth - century charitable Sailor's Snug Harbor, diverse dynamics mediated by class and gender played out across the landscape. Areas of the Sailor's Snug Harbor compound were segregated by gender, with women excluded from many areas and by class, with different placement and sizes of houses across the grounds and varying access to outdoor spaces (Baugher 2010). A similarly complex system of gender and class dynamics was documented at an Australian women's prison, where the social standing of both staff and inmates within the hierarchy was reflected both in the size and location of their residence. These positions of authority within the hierarchy were strictly gender segregated (Casella 1999). At the Magdalen Society in Philadelphia, inmates and staff were segregated by walls and strict rules about the use of space. Although staff and inmates ate their meals together as a symbolic domestic family, the recovery of only four transfer printed plates among a mix of whiteware with minimal, mismatched decoration suggests that the Matron and staff may have distinguished themselves from the inmates at table, "symbolizing the economic, social, and ideological distance that...separated the two groups" (De Cunzo 2001: 29).

In this issue, authors describe the different ways that the built environment was used to enforce and support the ideologies of reform, from the width of the maze in the soup kitchen to the separation of spaces between reformer and reformed, male and female, and the deserving and undeserving poor. Most of the papers in this volume focus on how landscapes and structures reflect both the ideologies of the reform projects that founded them, but also how resistance and changing ideologies have been made material. In schools, for example, children "learn and develop automatic responses to physical settings and surroundings; in the case of Northern Ireland schools, students learn gender segregation, appropriate [gendered] behavior, etc." (McKerr et al. this volume). In the US, standardization in the education of children was manifest in standardized designs for schoolhouses and playgrounds (Beisaw and Baxter, this volume).

Like schools, asylums and workhouses were planned environments. Asylums as built reflected and were physical manifestations of psychiatric theory and ideology. Over time, asylums remained in use as psychiatric approaches changed. Buildings were modified and expanded as possible to reflect these changes, but remain "interwoven 
with the material and ideological residue of the original" (Longhurst, this volume). For example, ideal institutional models for asylums in the nineteenth century organized buildings, landscapes, and procedures into a curative environment. At the turn of the twentieth century, this was largely replaced by medical treatments including surgery, physical therapy, and pharmaceuticals (Longhurst, this volume). Workhouses were designed to be visual reminders of reform to both the residents and to the reformers. For the reformers, known as Guardians, the "very sight of a well-built, efficient establishment would give [them] confidence" (Thomas, this volume). For the poor, the workhouse was designed to be miserable, to discourage them from relying on it. What was good order for the Guardians was, for inmates, "onerous work for the ablebodied, frugal diet; enforcement of cleanliness, order and ventilation, regulation of all aspects of life...marked by bell ringing, the wearing of a workhouse uniform" and confinement to the premises (Thomas, this volume).

Soup kitchens as well were designed to keep people off of assistance. They provided inexpensive soup (cheaper than bread) in the hopes that the poor would learn to live frugally and become self-reliant. Differences between the English and Jewish soup kitchens reflect divergent ideologies about both the poor and the role of reformers (Carstairs, this volume).

Like the more traditional institutions, playgrounds also embodied the ideologies of their designers. Different playground landscapes were built for use by different groups: young children; gender-segregated for older boys and girls; and almost all were racially segregated. "Playgrounds aimed to socially control children through contact with God's morally-reforming sacred natural world.... Ideally playgrounds included trees and bushes shading the small children's playgrounds and benches for mothers, and the edges of ballfields and tennis and volleyball courts for older boys and girls" (Spencer-Wood and Blackburn, this volume). Fences around playgrounds were there to keep out undesirable elements, and to create a safe, bounded environment for "respectable" people.

\section{The Unobtainable Ideal}

As demonstrated in all of these papers, reform is not a straightforward or simple endeavor; indeed, as some authors argue, it is the pursuit of an ultimately unobtainable idea. "Categories created by such projects are overwhelmed by the proliferation of hybrids that blur the very boundaries meant to constrain them. Theoretical divisions like nature/culture, western/non-western, Christian/heathen...produce results that can be characterized as inherently unstable when compared to the complexities of the real world" (Flexner, this volume). Because of this instability, reform projects must change and evolve to continue (Casella 2007). Materially, we also see differences in the ideal implementation of reform (theory) and what people actually do on the ground (practice). This variation between the ideal of something as designed versus how it manifests or is used in practice, has been addressed in other contexts, particularly in studies of planned landscapes (i.e., Low 2000; Strang 2008) but also in terms of specific objects and structures (i.e., Springate and Hayden 2005). This is a location where archaeology can also contribute to broader historical studies of reform. 
The driving forces behind the disjunction between theory and practice come from many different directions. Projects may neglect to take the lived realities of the reformed into consideration, as in the case of playgrounds in the US: "many poor children could not play during the day because they had to work in factories, in outwork at home, or in the streets" (Spencer-Wood and Blackburn, this volume). By the time reform projects get underway (after filtering through various planning, processes, and bureaucracies), they may be out of sync with contemporary principles and ideals. Existing structures, built for different purposes or reflecting other ideologies, may be used, as in the case of asylums and workhouses. Overcrowding (chronic and periodic) and management decisions can change how even purpose-built structures are used, violating the ideal distribution of people (Longhurst, Carstairs, and Thomas, this volume). Reformers on the ground may resist certain prescribed aspects of ideal plans, as did the workhouse builders in Ulster, who used earthen instead of wooden floors; sleeping platforms instead of beds; and rafters instead of ceilings (Thomas, this volume). Differences may also exist in response to resistance and negotiation by those targeted for reform, as described above.

\section{Archaeology as Reform}

While the main subject of these papers has focused on the archaeology of reform, authors were also asked to address how their work has represented archaeology as reform. Responses focused on the political practice of archaeology, and not on the concept of reform described by authors in their articles, with its air of paternalism and betterment of problematic or disadvantaged groups of people. Since the 1990s, there has been a movement in archaeology to recognize the political power of knowledge creation (Hodder 1991; Little 2002, 2009; Matthews 2004, 2009; Shackel 2001; Wood 2002). Increasingly engaged with social justice, these approaches are variously framed as emancipatory archaeology (Duke and Saitta 1998; Nida 2010); politically engaged archaeology (McGuire 2008; Smith 1999); critical archaeology (Leone et al. 1987; Leone 2010); heritage development (Shackel 2004; Smith and Waterton 2009); community archaeology (Wall et al. 2004); civic engagement (Little and Shackel 2007); restorative justice (Colwell-Chanthaphonh 2007); and activist archaeology (Stottman 2010). All of these may be considered examples of archaeology as reform.

In this volume, authors discuss archaeology as reform from several perspectives. Work at all of these sites also provide a glimpse of the tensions between intent and reality; and in theory and practice in both implementation and consequences. By studying these case studies and tensions, archaeology can inform and reform our understanding of how we currently perceive, understand, and implement social reform projects ranging from helping the poor to medical and religious institutions (Longhurst, Thomas, Carstairs, and Flexner, this volume). School buildings in both Northern Ireland and in the United States continue to be used as community, heritage, or arts centers. The archaeology at these places challenges narratives about education, memory, and society and ideas that educational reforms have had universally prosperous results (Thomas and Beisaw and Baxter, this volume). Finally, authors also connect their work to current social reform policies and problems, including national histories and health (Sables and Spencer-Wood and Blackburn, this volume). 
As we move forward, it is increasingly important to recognize the political uses of archaeology. As made very clear by Sables, the sites we choose to study, the questions we ask, the methods we use, the people we work with, and the interpretations we privilege all have social ramifications. Studying reform projects archaeologically can also serve to provide an understanding of the effects of underlying ideologies - the othering of people; reform as protective; how reform projects are modified; the power of practicality; ideology vs. implementation.

Acknowledgments Many thanks to all those who agreed to participate in the SHA session in Leiscester, and all those who attended and asked challenging and engaged questions. Many thanks also to Kim Christensen for wrangling this volume with me and her editorial eye, and to Paul Shackel and Chelsea Blackmore for their encouragement and assistance in thinking things through.

\section{References}

Battle-Baptiste, W. (2011). Black Feminist Archaeology, Left Coast Press, Walnut Creek, CA.

Baugher, S. (2001). Visible charity: the archaeology, material culture, and landscape design of New York City's municipal almshouse complex, 1736-1797. International Journal of Historical Archaeology 5: $175-202$.

Baugher, S. (2010). Sailors' Snug Harbor: a landscape of gender and power. In Baugher, S., and SpencerWood, S. M. (eds.), Archaeology and Preservation of Gendered Landscapes, Springer, New York City, pp. $165-187$.

Baxter, J. E. (2005). The Archaeology of Childhood: Children, Gender, and Material Culture, AltaMira Press, Walnut Creek, CA.

Baxter, J. E. (2008). The archaeology of childhood. Annual Review of Anthropology 37(1): 159-175.

Beisaw, A. M., and Gibb, J. G. (eds.) (2009). The Archaeology of Institutional Life, University of Alabama Press, Tuscaloosa.

Berkin, C. (2011). From the editor: American reform movements. History Now (30). https://www. gilderlehrman.org/history-now/2012-01/from-editor

Blackmore, C. (2011). How to queer the past without sex: queer theory, feminisms and the archaeology of identity. Archaeologies 7(1): 75-96.

Burns, A., and Innes, J. (eds.) (2003). Rethinking the Age of Reform: Britain 1780-1850, Cambridge University Press, New York.

Bush, D. R. (2000). Interpreting the latrines of the Johnson's Island civil war military prison. Historical Archaeology 34(1): 62-78.

Casella, E. C. (1999). Dangerous Girls and Gentle Ladies: Archaeology and Nineteenth Century Australian Female Convicts, Doctoral dissertation, University of California, Berkeley.

Casella, E. C. (2000). Bulldaggers and gentle ladies: archaeological approaches to female homosexuality in convict-era Australia. In Schmidt, R., and Voss, B. (eds.), Archaeologies of Sexuality, Routledge, New York, pp. 143-159.

Casella, E. C. (2007). The Archeology of Institutional Confinement, University Press of Florida, Gainesville.

Colwell-Chanthaphonh, C. (2007). History, justice, and reconciliation. In Little, B. J., and Shackel, P. A. (eds.), Archaeology as a Tool of Civic Engagement, AltaMira Press, Lanham, Maryland, pp. 23-46.

De Cunzo, L. A. (1995). The material culture of a woman's reform: the Magdalen Society asylum. Historical Archaeology 29(3): 35-100.

De Cunzo, L. A. (2001). On reforming the "fallen" and beyond: transforming continuity at the Magdalen Society of Philadelphia, 1845-1916. International Journal of Historical Archaeology 5: 19-43.

De Cunzo, L. A. (2006). Exploring the institution: reform, confinement, social change. In Hall, M., and Silliman, S. W. (eds.), Historical Archaeology, Blackwell, Malden, MA, pp. 167-189.

De Leiuen, C. (2015). "Corporal punishment and the grace of god": the archaeology of a nineteenth century girls' reformatory in South Australia. Archaeology in Oceania 50(3): 145-152.

Delle, J. A. (1998). An Archaeology of Social Space: Analyzing Coffee Plantations in Jamaica's Blue Mountains, Plenum, New York. 
Duke, P. and Saitta D. J. (1998). An emancipatory archaeology for the working class. Assemblage: University of Sheffield Graduate Student Journal of Archaeology 4. http://www.assemblage.group.shef.ac.uk/4 /4duk sai.html

Evans, E. J. (1999). Parliamentary Reform in Britain, ca. 1770-1918, Routledge, London.

Hodder, I. (1991). Interpretive archaeology and its role. American Antiquity 56(1): 7-18.

Hodge, C. J. (2014). Consumerism and the Emergence of the Middle Class in Colonial America, Cambridge University Press, New York.

Hollimon, S. (2000). Archaeology of the 'Aqi: gender and sexuality in prehistoric Chumash society. In Schmidt, R. A., and Voss, B. L. (eds.), Archaeologies of Sexuality, Routledge, New York, pp. 176-196.

Hollimon, S. (2009). Examining third and fourth genders in mortuary contexts. In Terendy, S., Lyons, N., and Janse-Smekal, M. (eds.), Que(e)rying archaeology, Chacmool Archaeological Association, Calgary, Alberta, pp. 171-175.

Huey, P. R. (2001). The almshouse in Dutch and English colonial North America and its precedent in the old world: historical and archaeological evidence. International Journal of Historical Archaeology 5: 123154.

Innes, J. (2003). "Reform" in English public life: the fortunes of a word. In Burns, A., and Innes, J. (eds.), Rethinking the Age of Reform, Britain 1780-1850, Cambridge University Press, New York, pp. 71-97.

Leone, M. P. (2010). Critical Historical Archaeology, Routledge, New York.

Leone, M. P., Potter Jr., P. B., and Shackel, P. A. (1987). Toward a critical archaeology. Current Anthropology 28: 283-299.

Lindauer, O. (2009). Individual struggles and institutional goals: small voices from the Phoenix Indian School track site. In Beisaw, A. M., and Gibb, J. G. (eds.), The Archaeology of Institutional Life, University of Alabama Press, Tuscaloosa, pp. 86-102.

Little, B. J. (2002). Archaeology as a shared vision. In Little, B. J. (ed.), Public Benefits of Archaeology, University Press of Florida, Gainesville, pp. 3-19.

Little, B. J. (2009). Reintegrating archaeology in the service of sustainable culture: Patty Jo Watson distinguished lecture in archaeology, American Anthropological Association Annual Meeting, Philadelphia, Pennsylvania.

Little, B. J., and Shackel, P. A. (eds.) (2007). Archaeology as a Tool of Civic Engagement, AltaMira Press, Lanham, Maryland.

Low, S. M. (2000). On the Plaza: The Politics of Public Space and Culture, University of Texas Press, Austin.

Marshall, Y. (2009). Archaeologies of resistance. In Terendy, S., Lyons, N., and Janse-Smekal, M. (eds.), Que(e)rying Archaeology, Chacmool Archaeological Association, Calgary, Alberta, pp. 12-20.

Matthews, C. N. (2004). Public significance and imagined archaeologists: authoring pasts in context. International Journal of Historical Archaeology 8: 1-25.

Matthews, C. N. (2009). Is archaeology political? transformative praxis within and against the boundaries of archaeology. Public Historian 31(2): 79-90.

McAtackney, L and Russell P (eds.). (2016). Colonial institutions: uses, subversions, and material afterlives. International Journal of Historical Archaeology 20(3): 471-476.

McGerr, M. (2003). A Fierce Discontent: The Rise and Fall of the Progressive Movement in America, Oxford University Press, New York.

McGuire, R. H. (2008). Archaeology as Political Action, University of California Press, Berkeley.

Meskell, L. (2002). The intersections of identity and politics in archaeology. Annual Review of Anthropology 31: 279-301.

Muncy, R. (1991). Creating a Female Dominion in American Reform, 1890-1935, Oxford University Press, New York.

Murray, P. (1999). Access to History: Poverty and Welfare, Hodder and Stoughton, London.

Myers, A., and Moshenska, G. (eds.) (2011). Archaeologies of Internment, Springer, New York.

Mytum, H., and Carr, G. (eds.) (2013). Prisoners of War: Archaeology, Memory, and Heritage of 19th-and 20th-Century Mass Internment, Springer, New York.

National Institute of Allergy and Infectious Diseases. (2011). Leprosy (Hansen's disease). National Institute of Allergy and Infectious Diseases. https://www.niaid.nih.gov/diseases-conditions/leprosy-hansens-disease

Nida, B. (2010). Emancipatory Archaeology of the Working Class, University of California, Berkeley.

Piddock, S. (2001). "An irregular and inconvenient pile of buildings": the Destitute Asylum of Adelaide. International Journal of Historical Archaeology 5: 73-95.

Shackel, P. A. (1993). Personal Discipline and Material Culture: An Archaeology of Annapolis, Maryland, 1695-1870, University of Tennessee Press, Knoxville.

Shackel, P. A. (2001). Public memory and the search for power in American historical archaeology. American Anthropologist 103(3): 655-670. 
Shackel, P. A. (2004). Introduction: working with communities. Heritage development and applied archaeology. In Shackel, P. A., and Chambers, E. (eds.), Places in Mind: Public Archaeology as Applied Anthropology, Routledge, New York City, pp. 1-18.

Smith, N. (1999). Confronting the Present: Towards a Politically Engaged Anthropology, Berg, New York.

Smith, L., and Waterton, E. (2009). Heritage, Communities, and Archaeology, Duckworth, London.

Spencer-Wood, S. M. (2001). Introduction and historical context to the archaeology of seventeenth and eighteenth century almshouses. International Journal of Historical Archaeology 5: 115-122.

Spencer-Wood, S. M., and Baugher, S. (2001). Introduction and historical context for the archaeology of institutions of reform. Part I: asylums. International Journal of Historical Archaeology 5: 3-17.

Spencer-Wood, S. M., and Baugher, S. (2010). Introduction: the archaeology and preservation of North American gendered landscapes. In Baugher, S., and Spender-Wood, S. M. (eds.), Archaeology and Preservation of Gendered Landscapes, Springer, New York City, pp. 1-18.

Springate, M. E. (2017). These knots cannot be untangled: a queer exploration of intersectionality and identity formation at Wiawaka Holiday House, Historical Archaeology, forthcoming.

Springate, M. E., and Hayden, P. (2005). Mitigation-level investigation, Vessel 92 (the MARICOPA), City of Perth Amboy, Middlesex County, NJ. Report on file with the New Jersey State Historic Preservation Office, Trenton, New Jersey.

Stottman, M. J. (ed.) (2010). Archaeologists as Activists: Can Archaeologists Change the World? University of Alabama Press, Tuscaloosa.

Strang, V. (2008). Uncommon ground: landscape as social geography. In David, B., and Thomas, J. (eds.), Handbook of Landscape Archaeology, Left Coast Press, Walnut Creek, California.

Surface-Evans, S. L. (2016). A landscape of assimilation and resistance: the Mount Pleasant Indian Industrial Boarding School. International Journal of Historical Archaeology 20: 574-588.

Voss, B. L. (2008). The Archaeology of Ethnogenesis: Race and Sexuality in Colonial San Francisco, University of California Press, Berkeley.

Wall, D. D. Z., Rothschild, N. A., Copeland, C., and Seignoret, H. (2004). The Seneca Village project: working with modern communities in creating the past. In Shackel, P. A., and Chambers, E. (eds.), Places in Mind: Public Archaeology as Applied Anthropology, Routledge, New York City, pp. 101-118.

Webster, N., and Porter, N. (1913). Webster's Revised Unabridged Dictionary of the English Language, G. and C. Merriam, Springfield, MA.

Weibe, R. H. (1967). The Search for Order: 1877-1920, Hill and Wang, New York.

Wilkie, L. A. (2000). Not merely child's play: creating a historical archaeology of children and childhood. In Dervenski, J. S. (ed.), Children and Material Culture, Routledge, New York, pp. 100-114.

Wood, M. C. (2002). Moving towards transformative democratic action through archaeology. International Journal of Historical Archaeology 6: 187-198. 